\title{
Territorialisation and power in Portuguese America. The creation of comarcas (16th-18th centuries)
}

\author{
Mafalda Soares da Cunha[1] \\ António Castro Nunes[2]
}

\begin{abstract}
The general aim of this article is to analyse the political organisation of the territory in Portuguese America from the start of the building up of the Crown judiciary system from in the 16th to the 18th centuries and to look into the causes of its belatedness in comparison to what happened in Spanish America. The focus will however be on the comarcas through the reconstitution of the process leading to the setting up of these judiciary divisions. Four stages of this process will be identified and discussion will ensue over the social and political contexts in which these political and administrative novelties came to happen. It is claimed that the delay in the structuring of the judicial network in the States of Brazil and Maranhão stems from the fact that the Portuguese advance into the territories took place at a later stage. The comparisons between the two systems will also bring other differences to the fore, not least the greater rigidity of the Spanish model in contrast to the more experimental character of the Portuguese one, and the resilience found to exist in the donatarial system. It is also worth to point out that given solutions were the result of the will of central power as much as of local initiative, and it is suggested that the building up of the crown's political apparatus (in which the judiciary network is included) brought about the connivance, albeit ephemeral, of social interests which are considered contradictory or irreconcilable by some authors.
\end{abstract}

Keywords: judiciary system; comarca; ouvidor-geral.

\section{Territorialização e poder na América portuguesa. A criação de comarcas, séculos XVI-XVIII}

\section{Resumo}

O objetivo geral deste texto é analisar a organização política do espaço na América portuguesa a partir da construção do aparelho judiciário da coroa entre o século XVI e o final do século XVIII, interrogando as causas de seu caráter tardio em comparação com a América espanhola. O enfoque é, no entanto, mais circunscrito. Partindo da reconstituição de todos os processos de criação das divisões judiciárias designadas como comarcas, apontam-se quatro fases nesse processo, para depois se discutirem os contextos sociais e políticos da fundação dessas novidades político-administrativas. Defende-se que o retardamento da estruturação da malha judiciária nos Estados do Brasil e do Maranhão decorre do avanço luso mais tardio sobre o território, embora o confronto dos dois sistemas torne patente outras diferenças. Desde logo, a maior rigidez do modelo espanhol em face do caráter mais experimental do sistema na América portuguesa, mas também a resiliência do modelo donatarial. Assinala-se ainda que as soluções encontradas resultaram tanto do voluntarismo dos poderes do centro quanto das iniciativas locais, sugerindo-se que a construção do aparelho político da coroa (nele incluindo-se a rede judiciária) podia concitar a conivência, mesmo que efêmera, de interesses sociais considerados por alguns autores contraditórios ou inconciliáveis.

Palavras-chave: sistema judiciário; comarca; ouvidor-geral.

\section{Territorialización y poder en la América Portuguesa. La creación de comarcas, siglos XVI-XVIII}

\section{Resumen}

El objetivo general de este texto es el análisis de la organización del espacio en la América portuguesa a partir de la construcción del aparato judicial de la corona entre el siglo XVI y el final del siglo XVIII, preguntándonos por las causas de su carácter tardío en comparación con la América española. El enfoque es, sin embargo, más restringido. Partiendo de la reconstrucción de todos los procesos de creación de las divisiones judiciales designadas como comarcas, se señalan cuatro fa ses en este proceso, para después pasar a discutir los contextos sociales y políticos de la fundación de esas novedades político-administrativas. Se sostiene que el retraso en la estructuración de la red judicial en los Estados de Brasil y Marañón se debe al avance luso más tardío sobre el territorio, aunque la comparación de los dos sistemas haga patentes otras diferencias. Desde luego la mayor rigidez del modelo español frente al carácter más experimental del sistema en la América portuguesa, pero también la resiliencia del modelo de donación. También se señala que las soluciones halladas fueron fruto tanto del voluntarismo de los poderes centrales como de las iniciativas legales, sugiriéndose que la construcción del aparato político de la corona (incluyendo en el mismo la red judicial) podía concitar la connivencia, aunque fuera efímera, de intereses sociales considerados por algunos autores como contradictorios o irreconciliables.

Palabras-claves: sistema judicial; comarca; ouvidor general.

\section{Territorialisation et pouvoir en Amérique portugaise. La création de comarcas (16ème-18ème siècles)}

\section{Résumé}

L'objectif général de cet article est d’analyser l'organisation politique du territoire en Amérique portugaise à travers la construction du système judiciaire de la Couronne entre le 16ème et la fin du 18ème siècle en questionnant les causes de son retard par rapport avec ce qui est arrivé dans l'Amérique espagnole. Le focus de l'analyse sera toutefois plus limité. D’après la reconstitution du processus de création des divisions judiciaires désignées comarcas on propose l'existence de quatre étapes et on discute ensuite les contextes sociaux et politiques dans lesquels ces nouveautés politiques et administratives se sont produites. On soutient que le retard dans la structuration du réseau judiciaire dans les États du Brésil et du Maranhão découle du caractère tardif de lavance portugaise dans le territoire, bien que la comparaison entre les deux systèmes présente d'autres différences. On constate ainsi la plus grande rigidité du modèle espagnol en contraste avec le caractère plus expérimental du cas portugais, n'oubliant toutefois le rôle joué par la résilience du système donatarial. On signale également que les solutions trouvées résultaient de la volonté du pouvoir central autant que de l'initiative locale, et, par conséquence, que la construction de l'appareil politique de la couronne (dans lequel le réseau judiciaire est inclus) résulte de la connivence, quoiquéphémère, d'une pluralité d'intérêts sociaux qui certains auteurs considèrent contradictoires ou inconciliables.

Mots-clés: système judiciaire ; comarca ; ouvidor-génèral 


\section{The starting point of the problem: historiography and empirical evidence}

$\Lambda$

fter deciding to study the political communication of the ouvidores-gerais (superior crown magistrates) of the states of Brazil and Maranhão with the monarchy, we were faced with various issues concerning the institutional architecture of justice in Portuguese America. The first, and the most obvious, is related to the territorialization of justice. When, at what pace, where and how was the network of comarcas (judicial and administrative districts) built? The answers found in the historiography were insufficient.

Since the pioneering work of Stuart B. Schwartz (2011a), the administration of justice has received some attention in the historiography. The most influential (and most controversial) Portuguese author in this process has been M. Hespanha (1994 and 2001), though his work has been followed by J. Subtil (1996) and N. Camarinhas's (2010) studies. Nowadays, in addition to a better understanding of the doctrinal structure and its legal framework, there are longue durée analyses (covering the seventeenth and eighteenth centuries) of the careers and the social profiles of the Portuguese magistracy in the early modern period and of the institutions for which they were responsible, especially the Desembargo do Paço (the highest court in Portugal). The growing interaction between the Portuguese and Brazilian historiographical communities transferred this interest to Brazilian post-graduate students. It is not worth discussing here either theoretical issues or the contours of the reciprocal influence of Portuguese and Brazilian historiographies, which Stuart B. Schwartz has recently summarized so well (2011b, pp. 114-118). Rather, we will just highlight that the majority of the recent papers have come from young historians and deal with the social history of the magistracy framed within the history of Portuguese overseas administration or the political practices of the ouvidores and their almost always troubled relationships with the local authorities. Common to almost all of them, however, is a discussion about the role of the state in the organization of ultramarine (overseas) societies and the opposing interpretations that A. M. Hespanha's work ${ }^{3}$ has given rise to.

Despite this noteworthy historiographical effort, the purpose of giving papers a strong empirical base has led to a narrow circumscription of what is studied. Although there are exceptions, such as Fiscais e meirinhos (Fiscals and Bailiffs), coordinated by Graça Salgado (1985) or Arno Wehling and Maria José Wehling's study of the High Court (Tribunal da Relação) in Rio de Janeiro (2004), the spatial unit of the analyses almost always coincides with a captaincy or a comarca, without moving beyond a single city or a relatively short period. On the other hand, the specific form of organization of the documentation of the Overseas Council, as well as the ease of access resulting from its online availability, has led these papers to privilege relationships between each of the territories and

${ }^{3}$ For some of the examples, see infra the bibliography attached to the maps about the creation of the comarcas. 
the various political centers, such as Lisbon, Bahia or, later on, Rio de Janeiro, to the detriment of the internal dynamics of Portuguese America as a whole. What is important is a greater crosschecking of the various types of documentation, in addition to more dialogue and more explicit comparative attention between the diverse cases studied which would facilitate the preparation of long-term overall syntheses about various themes. One such example would be the territorialization of justice.

However, the creation of new comarcas is not a new theme, nor is it limited to the strict field of the history of justice. Even if indirectly, various scholars have dealt with this issue since the nineteenth century, though often with the intention of clarifying the territorial limitations between the states in which there were centuries-old disputes. This is precisely what happened, for example, regarding the frontiers between Sergipe and Bahia (Lima Junior, 1914; Prado, 1919). Another area of study about the spatialization of power comes from the crossovers between historical geography (Moraes, 2000), urbanism and the history of the cities (Reis Filho, 1968) and, more recently, with the cultural history and the history of cartography. ${ }^{4}$ The concern with the meanings of the territorialization of administrative practices and political discourses even allowed Íris Kantor to propose, above all for the second half of the eighteenth century, the existence of a rupture with political models with medieval roots, suggesting that the Portuguese colonies had been a fundamental field for the experimentalism of new formulas for sovereignty (Kantor, 2009, p. 234).

Whilst these may be the original motivations for this study, there are other questions that were emerged during the research about the creation of comarcas in Portuguese America between the sixteenth and eighteenth centuries.

It is well-known that, according to doctrinal sources from the medieval and early modern periods and from studies about the political and institutional history of early modern societies for various European monarchies (Hespanha, 2005, p. 216; Schwartz, 2011a, p. 290), the administration of justice was the main sphere of governance in the Ancien Regime, in part because it was more directly connected to the figure of the king. The monarch had to guarantee that each individual would receive what he was due, which also had to be done according to "a particular organizational, procedural and intellectual methodology, which could guarantee the adequate deliberation of various points of view," (Hespanha, 2005, p. 216). It is, thus, circumscribed in what is called the jurisdictionalist paradigm of governance which was dominant in the Iberian monarchies until at least the beginning of the eighteenth century. In this perspective, the administration of justice constituted from very early on a priority area within the organization of society.

Accepting this assumption, how can we explain that the structuring of the judicial system in Portuguese America occurred so late and so slowly, especially when contrasted with Spanish America? Does answer lie in the imperative and urgent volunteerism assumed by the Spanish crown given the demographic

${ }^{4}$ Some examples are the papers of historians such as Júnia Ferreira Furtado and Íris Kantor. 
density and complexity of the social and political organization of the society that already inhabited the American territories? Had the Pre-Columbian structures of territorial organization - in many cases coincidental with the ones created afterwards - not allowed the premature structuration of the judicial network in Spanish America supported by a foundation with more cabildos than municipal councils? Moreover, did this swiftness not come from the enormous necessity to also guarantee control over recently discovered mineral resources in Upper Peru?

\section{How can we explain that the structuring of the judicial system in Portuguese America occurred so late and so slowly, especially when contrasted with Spanish America?}

Although some authors emphasize some aspects more than others do, in general there is a consensus about the importance of all these factors to explain the differences between the initial forms of Castilian and Portuguese colonization. It is noted that between 1511 and 1565, the judicial network in Spanish America consisted of 10 judicial districts - the audiencias - which included the entire territory of the viceroyalties of New Spain (created in 1535) and Peru (founded in 1542). This network remained stable, with the exception of the audiencia of Buenos Aires, created in 1661. Between the sixteenth and seventeenth centuries, around 35 governors subordinate to the two viceroyalties held administrative functions in the entire territory of Spanish America (Elliott, 2007, p. 125). It is worth highlighting, however, that the court network was established earlier in the American conquests than in Castile itself, since around the sixteenth century there were only two chancillerías and three audiencias under the Castilian Crown: Valladolid, Granada, Galiza, Seville and the Canaries (Eiras Roel, 1982; Gómez González, 2003). In the framework of the Bourbon Reforms, the number of viceroyalties increased with the creation of Nova Granada (1739) and Rio da Prata (1776). This reorganization reached the audiencias, producing some instability: some were abolished, later being reconstituted, while two others were created (Caracas and Cuzco). Thus, on the eve of independence, there were 12 audiencias in all of Spanish America (Lucena, 2005, p. 107). The magistrates of the audiencias were royally appointed, although it is important to indicate that these posts could be sold, which happened massively between 1680 and 1750 .

In a flagrant contrast with this rate of progress, in 1609 there were only two judicial districts in Portuguese America - the comarcas or ouvidorias-gerais ${ }^{5}$

${ }^{5}$ In this context, we assume that both designations are equivalent, although there may be some differences (Silva, 2014). 
—, headed by a magistrate appointed by the king of Portugal. There was, however, an undetermined number of officials with judicial functions appointed by the capitães-donatários (the donatary captains or hereditary captains, also called capitães-mores or captain-majors). However, the first territorial division of Brazil was not much later than in Spanish America. It occurred in 1530, with the concession of 12 captaincies to capitães-donatários by the crown, although only in 1549 was a governor-general created who was based in Bahia, responsible for all of Brazil. In 1618 the state of Maranhão was created, with a capital in São Luís. Nevertheless, until the 1680s there were no more than six comarcas, a number which grew significantly in the following decades (see Table 1). At the beginning of the nineteenth century, the number of these judicial districts was 23, ${ }^{6}$ while the political division between the state of Brazil and Maranhão remained, with the varying designations that the latter assumed. ${ }^{7}$ At this point, all of the officials who headed the 23 comarcas had already been royally appointed. As A. M. Hespanha explained long ago, these magistrates needed to be literate, had intermediate jurisdiction and did not obtain positions through the costly route, which, as we have seen, differentiated them from the magistrates of Spanish America. At the base of the judicial system were the locally elected justices, since the appearance of juizes de fora (literally judges from afar) was even later than that of the ouvidores-gerais, and only began to spread throughout Portuguese America in the 1690s.

The delay in the implementation of the crown's judicial network in Brazil deserves further reflection, since the model for judicial organization that came to be applied in the Portuguese conquest essentially traces the institutional architecture of the Kingdom of Portugal. Furthermore, it was defined in the metropole at the beginning of the sixteenth century. Indeed, in the middle of the 1500s, the Kingdom of Portugal covered an area of approximately 90,000 $\mathrm{km}^{2}$, divided into 27 judicial districts of unequal sizes and with a varying number of municipalities under them. Similar to what occurred in Brazil, the officials who headed these districts could be appointed by the Crown, assuming the title of corregedores, or by the jurisdictional lord (noble or cleric), in which case they were titled ouvidores. The judicial network grew to 32 in 1640, then to 44 at the beginning of the nineteenth century, reaching 48 in 1826, including the districts headed by magistrates appointed by the crown or nobility (Monteiro, 1996, p. 85; Silva, 1998). In the seventeen century, the latter corresponded to approximately one third of the total number of appointments. In Portugal a common characteristic during the entire period in question was the non-existence of intermediate governing divisions equipped with their own

\footnotetext{
${ }^{6}$ For the end of the eighteenth century, Nizza da Silva refers to a total of 24 comarcas, with differences to our survey (she reports Itu, Porto Alegre and Rio Grande Norte, and does not include Santa Catarina and Piauí), nor does she list the sources where the data collected (Silva, 1994, pp. 24-25).

${ }^{7}$ In 1654, it was renamed the state of Maranhão and Grão-Pará, and 1751, the state of Grão-Pará and Maranhão. In 1771, it was separated into the state of Maranhão and Piauí and the state of Grão-Pará and Rio Negro. It only became part of the state of Brazil when the Portuguese court moved to Brazil.
} 
political competences, contrary to what was found in Portuguese America with its governors and capitães-mores in the captaincies.

But are the American audiencias comparable to the comarcas or the ouvidorias-gerais? In reality, there were substantial differences between them. The audiencia was a higher court with judicial and (arguably) governmental powers within its jurisdiction and collegial decision-making powers, while the ouvidor-geral was the magistrate responsible for the administration of justice in each comarca, though appeals could be made to higher courts, which had collegial decision-making powers. In the state of Brazil, the ouvidores-gerais answered to the High Court (Tribunal da Relação) in Bahia, (1609-1926 and 1652) and, after 1751, also to the new High Court created in Rio de Janeiro. While in the case of the state of Maranhão, up until the beginning of the 1800s, appeals went to Casa da Suplicação (or Court of Appeals) in Lisbon. Furthermore, the High Court of Bahía was also founded late (1609) when compared with the effulgent establishment of the network of American audiencias. This perception becomes even more acute since it is known that the regular operation of the High Court of Bahia (Tribunal da Bahia) is later (1652) and that only a century afterwards and with the growing relevance of the South-Central regions in Brazil was another higher court established in Rio de Janeiro (1751). This comparison between the ouvidorias of Portuguese America and the Spanish judicial network also has to take into account the corregimientos. These districts, partially modelled on peninsular examples, were headed by an official who, in addition to being a judicial official, also had governmental functions such as being the president of the municipal cabildo (council). In some ways. the competences of the ouvidores-gerais were similar, though in many other aspects, as in the case of the social profile of the corregidores, there were clear differences.

This text has the general objective of analyzing the political organization of space in Portuguese America through the construction of the judicial system between the sixteenth century and the end of the eighteenth. The central focus, nevertheless, will be more restricted. Starting with the reconstitution of all of the Portuguese Crown's creation processes of the judicial divisions designated as comarcas, these will initially be interpreted in terms of their periodization and their regional structure. Subsequently, the contexts of the creation of these new political-administrative bodies will be discussed, with the assessment of the arguments of various participants involved in these processes, in order to clarify the variety of social and political interests present, as well as their geographic distribution.

\section{Territorialization of power in Portuguese America in the sixteenth - eighteenth centuries.}

The first territorial division in Brazil occurred in the 1530s and involved the concession by the Crown of portions of the coast of Brazil to various private parties, who were appointed as hereditary captains or donatary captains 
(capitães-donatários). The donation charters granted to these lords shared various similarities with the letters of donation of full jurisdiction which the Portuguese monarch grated to nobles in Portugal. This signified the delegation of ample powers to govern particular locations, including the administration of the judicial, economic, fiscal and military spheres. Similarly, the responsibility of creating an administrative system and the right to appoint its respective officials were transferred to the overseas donataries. Although the model implied the presence of these individuals in the territories they administered, this was not demanded, which allowed the donatary captains to almost always delegate these roles to people of their confidence.

\section{The model for judicial organization that came to be applied in the Portuguese conquest essentially traces the institutional architecture of the Kingdom of Portugal}

What is important to note here is that, in the period when the hereditary captaincies were the only form of organizing territory, there were coincidences between the political and judicial districts. As a result, while the name ouvidor thereby contains the memory of this seigniorial origin, the truth is that they were appointed by the donatary captain without the prerequisite of having an academic education and, because of this, were excluded from the prior assessment of the technical merits required by law. In reality, this designation and these roles were often accumulated by the capitães-mores along with the military and fiscal functions. This allowed a subsequent development which was the possibility of transferring the proprietorship of these functions, even the judicial ones, to third parties. While the accumulation of competences was a solution to overcome the absence of magistrates which the Crown would also come to practice, the possibility that the donatary ouvidores had to actually own their position or even hold it as public officials, and rather than with the triennial mandates stipulated in the Ordenações, is specific to the system of hereditary captaincies.

It is worth highlighting, however, that the long term coexistence of the Crown's captaincies and the hereditary captaincies signified the coexistence of two different models of government and judicial administration, although the lordship model had been losing vigor since the seventeenth century, as A. Vasconcelos de Saldanha (2000) has demonstrated. The process was, nevertheless, far from linear and did not follow any prior schedule set forth by the monarchy, thereby differing it from the general reorganization carried out by João III or the unsuccessful 1790s attempt at reforms in Portugal. In Portuguese America, it responded, above all, to the concrete situations that emerged there and resulted in complex political arrangements between various authorities present on the territory, with its end occurring only in the second half of the 1700s. 
From a spatial point of view, the jurisdiction of officials of justice in the donatary captaincies always coincided with the territory of the hereditary captaincies. In addition, the judicial organization of the Crown, initiated only in the 1500s, created another network which overlaid over this one, without nullifying it. It began by having full jurisdiction over the entire territory and was later subdivided into spatial units - the aforementioned comarcas or ouvidorias -, whose configuration did not always coincide with the sixteenth century captaincies and did not always follow the pace of the creation of new captaincies in the eighteenth.

As is well-known, the Portuguese occupation initially concentrated on the Northeast coast, with territorial expansion occurring along the coast in opposite directions: northwards and southwards. It is not surprising then, that the main spatial dynamics of the evolution of the system of governance were constructed from this dual orientation: one in the Northeast, regarded as the central region until the seventeenth century, heading northwards and southwards and covering Pernambuco, Bahia, Maranhão and Rio de Janeiro; another, that emerged later, heading inland from the coast, corresponding, above all to the captaincies of Rio de Janeiro, São Paulo and Maranhão, in the 1700s. Consequently, there emerged 'poles of colonization sprawl' in different parts of the coast, to use the expression of the geographer A. C. Robert de Moraes (2000). These allowed some captaincies to make themselves the main captaincies, subordinating other preexisting or recently created ones, which the documentation refers to as annexed or subordinated.

In the functional sphere, the tendency of the judicial system was for increased complexification, through the creation of a hierarchical model with the subordination of seigniorial ouvidores to the royal ouvidores and the latter to the appellate judges of the Bahia and Rio de Janeiro Courts of Appeal, and all of them to the higher courts in Lisbon and to the King. The process was revealed to be time consuming and full of conflicts, since it faced resistance at the base of the system, in relation to municipalities, and at the top with the governors or capitães-mores in the captaincies (including the donatary ones) and with the general governor. The result was multiple jurisdiction conflicts that, has been well established in the historiography, were endemic to the dominant political culture.

This brief explanation has the purpose of introducing a proposal for establishing a chronology of the territorialization of justice in Portuguese America from the analysis of the creation of the 23 comarcas previously mentioned here (Table 1 and Maps 1 and $2^{8}$ ). The data was constructed using the available bibliography, various monographies, and case studies which have recently emerged in the Brazilian historiography, complemented by the documentation from the Overseas Council.

${ }^{8}$ We would like to thank Tiago Luís Gil, from the Universidade Federal de Brasilia, for preparing the two maps according to the research data. Atlas Digital da América Lusa (version 2.0). Available at: <http://lhs.unb.br/ i3geo>. Accessed on: 17 Dec. 2013. Altered for the purposes of illustration. 


\section{The construction of the judicial system in four phases}

We have already mentioned that when compared with the Kingdom of Portugal, the number of comarcas present in Portuguese America is low. At the beginning of the 1800s there were 44 comarcas in Portugal, while they did not exceed 23 in Portuguese America. It is important, then, to highlight that in both cases the network of comarcas grew, albeit at different paces. In the case of the American conquests, in the approximately 150 years between the foundation of the second comarca and the date of creation of the last one in 1763, 22 ex novo were created. At the same time, the territory controlled by the Portuguese monarchy grew beyond measure. In other words, the royal judicial system was implanted, defined and constructed in an extensive space with constantly open borders.

\section{When compared with the Kingdom of Portugal, the number of comarcas present in Portuguese America is low}

But, other elements have to be considered to explain the shape assumed by the network of comarcas during these three centuries. Demographic growth is certainly the most telling. While, in the middle of the sixteenth century the Kingdom of Portugal had a population of around 1,500,000, in 1801 this number had reached three million. In other words, it doubled. Although in the case of Brazil the demographic data is quite uncertain, Maria Luiza Marcílio calculated that there were around 20,000 European colonists in 1570 and around 30,000 in 1580. Around 1600, it is estimated that the total population which was subordinate to the Portuguese authorities (including people of African descent and subjected Native Americans) was 100,000 people, a number which had tripled by 1700 with the overall population reaching around 300,000 (Marcílio, 2000, pp. 46-47). In a recent study, A. Carrara was even more cautious, giving a total of slightly over 200,000 for Brazil and Maranhão together (Carrara, 2014, pp. 17-21). The intense rate of (voluntary and forced) immigration, recognized by all the authors as having occurred in the eighteenth century, allowed Dauril Alden to make an estimate of a little over 1.5 million inhabitants around 1776 and 2 million around 1800 (Alden, 2000, pp. 308-309), although there are less restrained calculations that suggest 3 million (Livi Bacci, 2002, p. 145). However, there is a consensus about the rapid growth of the population in the eighteenth century, resulting from an acceleration in the arrival of Portuguese colonists and slave labor in Brazil, which peaked in the 1720s and 1730s after the discovery of gold inland in the South-Central region. Less is known about the territorial distribution of this population, but studies suggest a concentration of the new arrivals in the mining zones, along with the conservation of the most elevated demographic densities in some coastal regions in the northeast and in the main ports in the 
South-Central region. At the beginning of the nineteenth century, the captaincies of Pernambuco, Bahia and Rio de Janeiro concentrated around $62 \%$ of the total population of Portuguese America, while $19.7 \%$ were found in the captaincy of Minas Gerais, equivalent to a little over 400,000 inhabitants (Alden, 2000, p. 308). In other words, with the exception of Minas Gerais, the largest population density in the occupation of the territory remained almost unaltered in comparison with the characteristics of the initial settlement.

Let us turn to the four stages of the construction of the judicial system in Portuguese America.

Table 1. Chronology of the establishment of comarcas in Portuguese America (16th-18th centuries)

\begin{tabular}{|c|c|c|c|c|}
\hline Based in & Comarca & Date & $\begin{array}{l}\text { Dismembered } \\
\text { from }\end{array}$ & Captaincy \\
\hline Salvador & Bahia & 1548 & - & Bahia \\
\hline Rio de Janeiro & Rio de Janeiro & 1608 & Bahia & Rio de Janeiro \\
\hline São Luís & Maranhão & 1619 & Bahia & Maranhão \\
\hline Belém & Pará & 1652 & Maranhão & Grão-Pará \\
\hline Olinda & Pernambuco & 1653 & Bahia & Pernambuco \\
\hline $\begin{array}{l}\text { Nossa Senhora das } \\
\text { Neves }\end{array}$ & Paraíba & 1688 & Pernambuco & Paraíba \\
\hline São Cristóvão & Sergipe & 1696 & Bahia & Bahia \\
\hline São Paulo & São Paulo & 1700 & Rio de Janeiro & São Paulo \\
\hline $\begin{array}{l}\text { Santa Maria } \\
\text { Madalena }\end{array}$ & Alagoas & 1709 & Bahia & Bahia \\
\hline Vila Rica & Ouro Preto & 1711 & São Paulo & Minas Gerais \\
\hline Sabará & Rio das Velhas & 1711 & São Paulo & Minas Gerais \\
\hline São João del-Rei & Rio das Mortes & 1713 & São Paulo & Minas Gerais \\
\hline Vila do Príncipe & Serro Frio & 1720 & Rio das Velhas & Minas Gerais \\
\hline Mocha & Piauí & 1722 & Maranhão & Piauí \\
\hline Paranaguá & Paranaguá & 1723 & São Paulo & São Paulo \\
\hline Aquiraz & Ceará & 1723 & Pernambuco & Ceará \\
\hline $\begin{array}{l}\text { Vila do Bom Jesus } \\
\text { de Cuiabá }\end{array}$ & Cuiabá & 1728 & São Paulo & Mato Grosso \\
\hline Vitória & Espírito Santo & 1732 & Rio de Janeiro & Espírito Santo \\
\hline Vila Boa de Goiás & Goiás & $1733(?)$ & São Paulo & Goiás \\
\hline Santo Antônio & Jacobina & 1734 & Bahia & Bahia \\
\hline Santa Catarina & Santa Catarina & 1749 & Rio de Janeiro & $\begin{array}{l}\text { Rio Grande S. } \\
\text { Pedro }\end{array}$ \\
\hline Cairu & Ilhéus & 1763 & Bahia & Bahia \\
\hline Porto Seguro & Porto Seguro & 1763 & Bahia & Bahia \\
\hline
\end{tabular}


The first phase runs from 1548 until the expulsion of the Dutch. It witnessed the creation of four royal ouvidorias-gerais in Salvador, Bahia in 1548, in Rio de Janeiro in 1608, in São Luís, Maranhão in 1619 and in Olinda, Pernambuco in 1653. There is evidence suggesting that the ouvidoria-geral of Pará was created in 1652, although the regular appointments of magistrates for this post occurs much later, which allows it be supposed that this decision is only stabilized in the 1680 s.

The draft of the first royal judicial map coincides almost perfectly with the solutions of governance tried during the first six decades of the seventeenth century for the different parts of Brazil: the state of Brazil, the Southern Division (Repartição Sul) and the state of Maranhão (see Map 1). Although the success of these experiences of political organization varied — only the states of Brazil and Maranhão remained relatively stable —, it is our opinion that they had a deciding impact over the initial evolution of the network of comarcas.

It can be noted that in the sixteenth century there was only one governor-general and a single royal judicial district in all the parts of Brazil. Given the name ouvidoria-geral do Brasil, it was based in Salvador. Between 1572 and 1577 the authorities in the South were able to obtain from the Crown the division of this extensive territory into two separate governments, based in Rio de Janeiro and in Salvador. The idea created some resistance among the Northeastern elites, but not among the governing elite in the South; on the pretext of the promise of discovering mines, the division was recreated between 1608 and 1612 with the name Southern Division (Repartição Sul) and it led to the establishment of the second ouvidoria-geral in the Portuguese conquest in 1608, also based in Rio de Janeiro. At this moment, the jurisdiction of the government of the Southern Division and the comarca in Rio de Janeiro was the same: it included the so-called captaincies of the South, in other words, Espírito Santo, São Vicente (both donatary captaincies), and Rio de Janeiro. Although the governing experience did not have many results at this point, the same did not occur with the ouvidoria-geral, since it persisted without interruption until the beginning of the eighteenth century. However, due to the insistence of the Rio de Janeiro elite, the division of governance was reinstated with an identical designation and equal jurisdiction between 1658 and 1662, at which point it definitively disappeared as structure of governance. It is important to emphasize that the ouvidor-geral from Rio de Janeiro had judicial supervision rights over the donatary captaincies, despite these having their own ouvidor appointed by the donatary, which gave them an unarguable jurisdictional superiority in this region. 
Map 1. Chronology of the creation of comarcas - 1st and 2nd phases ${ }^{9}$

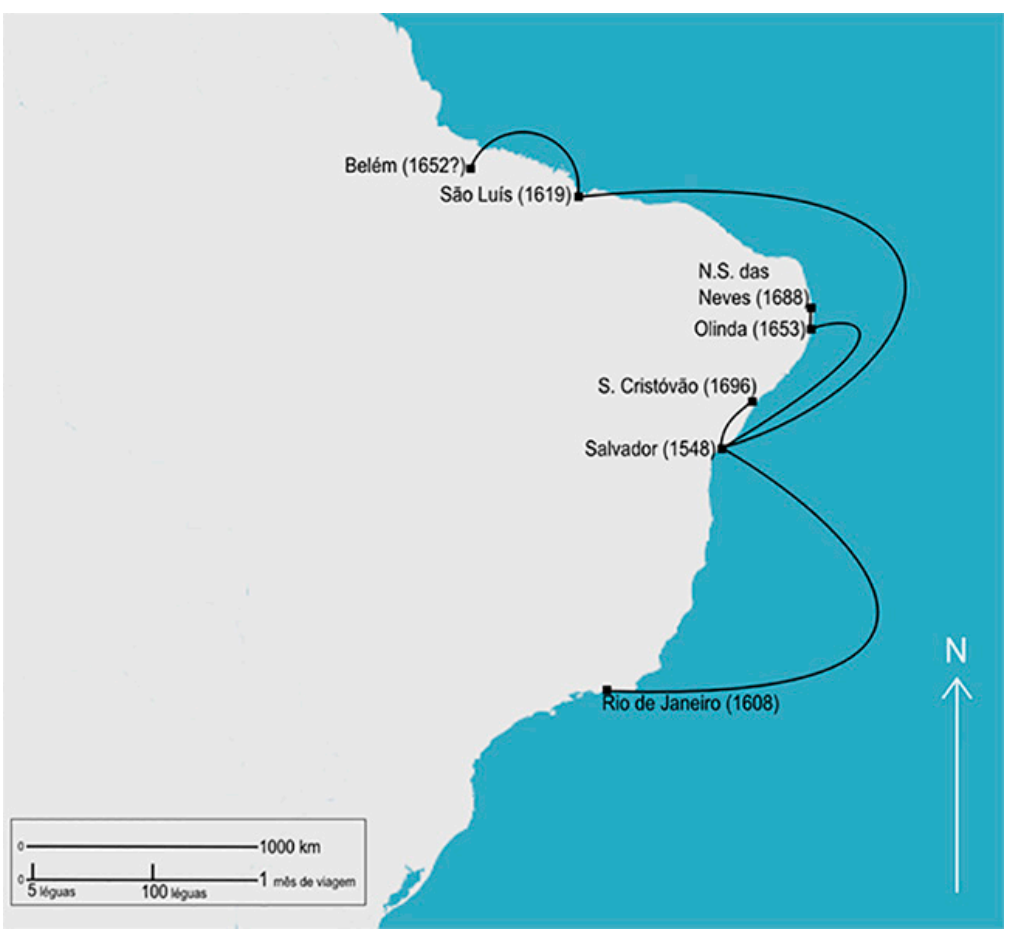

Returning to the ouvidoria-geral of Brazil and the beginning of the seventeenth century. After the creation of the comarca in Rio de Janeiro, the area of jurisdiction of the comarca of Bahia integrated the captaincies which were subordinated to the captaincy of Bahia, in addition to the donatary captaincy of Pernambuco and its annexes. But, in 1653, this large comarca of the state of Brazil (which also came to be called Bahia) underwent a second territorial desegregation with the establishment of the ouvidoria-geral in Olinda (Pernambuco).

The late appearance of a ouvidoria-geral appointed by the Crown in Pernambuco, notwithstanding the importance of the weight of the dynamic

\footnotetext{
9 The new comarcas are connected by a curved line with the ones they were disaggregated from. Sources and bibiography for the preparation of the of the maps: Bahia (1548) - Schwartz, 2011; Rio de Janeiro (1608) — Mello, 2012, p. 13; São Luís (1619) — Regimento do Ouvidor do Maranhão: Available at: <http://www. iuslusitaniae.fcsh.unl.pt/verlivro.php?id_parte=95\&id_obra=63\&pagina=1335>; Olinda (1653) - Silva, 2010; Nossa Senhora das Neves (1688) — Menezes, 2005; São Cristóvão (1696) — Carvalho Lima Junior, 1914, p. 9-49; Prado, 1919; São Paulo (1700) - Pegoraro, 2007; Santa Maria Madalena (1709) - Caetano, 2009, p. 21; Vila Rica (1711) — Sousa, 2012, p. 17; Sabará (1711) - Sousa, 2012, p. 17; São João del-Rei (1713) — Sousa, 2012, p. 17; Vila do Príncipe (1720) - Fonseca, 2011; Furtado, 1994; Mocha (1722) — Jucá Neto, 2012; Costa, 1909; Paranaguá (1723) - Pegoraro, 2007; Aquiraz (1723) — Jucá Neto, 2012; Vila do Senhor Bom Jesus de Cuiabá (1728) — Jesus, 2009, p. 3; Vitória (1732) — Rubim, 1861; Mello, 2012; Vila Boa de Goiás (1733-1736) - Arquivo Histórico Ultramarino (AHU), "Carta de governador e capitão general de capitania", São Paulo, box 2, doc. 104; Santo Antônio de Jacobina (1734-1743) - AHU, "Carta de Vasco Fernandes César de Menezes ao rei d. João V", Bahia, box 21, doc. 1842; Santa Catarina (1749) - Silva, 2007, p. 72; Porto Seguro (1763) - Azevedo, 2015; Cairu (1763) - Adan, 2009, p. 11.
} 
characteristic of the occupation which justifies its classification as a sprawling center of colonization, as previously mentioned, is due to the fact that the captaincy remained as a hereditary captaincy during a large part of the seventeenth century. In effect, the donatary captaincies preserved the privilege of appointing the ouvidores-gerais, although the Crown demanded that they have a Law degree (Assis, 2001, p. 76). This situation was only altered in the wake of the expulsion of the Dutch from the captaincy, when the governor-general of Brazil present in Pernambuco, given the need to reinstall Portuguese administration in the region, appointed an ouvidor. However, and as previously stated, the first royally appointed magistrate was in 1653 and, like the governor of Pernambuco, retained jurisdiction over the captaincies of Itamaracá, Rio Grande do Norte and Paraíba. The justification for such a large jurisdictional district came from a combination of factors. It came, on the one hand, from the maintenance of the superiority which the Dutch had bestowed upon Pernambuco when they made Recife the base of their conquest, and in formalizing the annexation of these three captaincies to the jurisdiction of Pernambuco in 1630 (Assis, 2001, p. 84). On the other hand, due to the importance that the elites from Pernambuco had, not only in the initial conquest of the territory to the north but also in the combat against the Dutch occupation in this entire area.

\section{The creation of the High Court in Bahia made the capital of the state of Brazil superior to the then recent comarca of the Southern Division}

Almost simultaneous to the initiative of the creation of the Southern Division and its own ouvidoria-geral, the High Court of Bahia was created in 1609, though it did not last long (1609-1626). All cases from the state of Brazil could be appealed there. In connection to what we have sought to establish about governmental experiences attempted in the seventeenth century and the creation of the comarcas, it is worth remembering that the creation of the High Court in Bahía made the capital of the state of Brazil superior to the then recent comarca of the Southern Division. The willingness to create clear political hierarchies within the Portuguese Americas, which was felt during the rule of the House of Austria, was nonetheless continued in the Post-Restoration Period. Related to this, are both the reinstating of the Court of Bahia in 1652 and the tendency to affirm the governor-general of Brazil over the governors of the main captaincies of Rio de Janeiro and Pernambuco, which would be definitively stipulated in the 1678 regulations. ${ }^{10}$

${ }^{10}$ Chap. 39, Regimento de Roque da Costa Barreto, 1678 (Mendonça, 1972, p. 804; Cosentino, 2009, pp. 257-265). 
Farther north, the state of Maranhão and Grão-Pará was officially created in 1618 , although the appointed governor only took office in 1621. He had jurisdiction over a territory whose limits varied over time, but whose first definition in 1624 covered the recently created captaincies of Maranhão, Ceará and Pará, with a capital in São Luís. The ouvidoria-geral of Maranhão was, as mentioned above, created in 1619 and its territory coincided with that state until the end of this initial phase of the creation of the comarcas. Along with the already known geostrategic reasons (Marques, 2010), the fact that the superior court for the ouvidor of Maranhão was the High Court in Lisbon, and not the High Court in Bahia, helps explain the precocity of the creation of this ouvidoria-geral, as well as the stability of the governmental separation from the state of Brazil.

Before finishing the description of the first phase of the creation of the comarcas, it is important to emphasize that what gives it unity and makes it different from the remaining periods is its markedly experimental features, in the sense that Íris Kantor attributes to it. In other words, despite having been unsuccessful, there seemed to be attempts to build a tripartite organization for the government of the Portuguese Americas. This fact, which is specific to this phase, cannot, however, be understood either as fruit of the Castilianization of the Portuguese model of administration (Cosentino, 2009, pp. 42-49 and 120126), nor as the results of the reformist practices of the Austrian monarchy, since they were continued following the acclamation of João IV. The expression the "institutionalization of the state of Brazil," used by ${ }^{11}$ Guida Marques, is best applied to this reality, although it should be pointed out that the institutional densification which occurred in Portuguese America is not specific to this conquest, since it also occurred in other overseas Portuguese territories. Nor is the experimentalism mentioned exclusive to this period, since it would bloom at various moments during the eighteenth century and not always independently of the Crown. The institutional experiences of this phase suggest, then, a model of territorialization which was still hesitant, oscillating between the social and political interests of the locals whose often contradictory dynamics shaped themselves at times into attempts at a tripartite division of territory, and at other times into a more hierarchical densification of the political system in place in the primitive division of the captaincies. And, as it will be seen below, the authorities in the metropole shared a good part of this hesitation about the model to be adopted.

The second phase of the chronology covers the last decades of the seventeenth century, and can be classified as a transition phase with a reduced expression at the level of the judicial network of the ouvidorias-gerais, since only two were created and the one from Pará was stabilized, as previously mentioned. In 1688, an ouvidor was appointed to Paraíba based in Nossa Senhora das Neves (now João Pessoa), dismembering the comarca of Pernambuco to the North and including in its judicial supervision the territories of Itamaracá,

"Although it is a concept that has been explained in earlier papers by the author, see Marques (2013, $\mathrm{p}$. 231-252). 
Rio Grande, and later on Ceará (Menezes, 2005). In 1696, the ouvidoria-geral of Bahia suffered a new desegregation following the installation of the ouvidor of Sergipe to the north, in São Cristóvão. The new comarcas were based in urban centers near the coast, with a territorial delimitation, that was almost always conflicting, imprecise and rather unstable, which recovered in part the memory of the 1500s drafting and designation of captaincies, which, as it is known, were established on the coast.

As Map 1 shows, the geographic area privileged in this second phase was the Northeast. In addition to corresponding to the political aspirations of the social elite involved in reconquering this area, other explanations for this fact are based on the need to frame the Portuguese presence more efficiently in one of the first irradiating centers of colonization after the submission of the native populations following the so-called Barbarian War and due to expansion into the sertão stimulated by cattle raising (Gomes, 2010). But the first news of the discovery of mines in the South-Central region in the 1690s also contributed to stabilizing the model of judicial organization established in the royal comarcas. Although their territorial boundaries were still quite ample, the new comarcas tended to coincide more with the districts of the captaincies from the 1500s. As far as governance is concerned, the Crown resumed the territorial division of self-governing captaincies, now with governors appointed or confirmed by the king, but also dependent on a single governor-general of Brazil with added authority. Thus, the general tendency of this phase set a model for institutional organization with greater separation between the spheres of government and the judicial administration, while at the same time highlighting the weakening of the donatary system.

Another new aspect during this second phase was the densification of judicial structures, with the establishment of other royal territorial magistrates, this time with a municipal scope: the juizes de fora. The first was appointed to Bahia in 1696, while in the metropole these posts appeared during the fourteenth century. In Brazil, the pace of the spread of the juizados de fora (courts for the 'judges from afar') intensified later (in what we refer to as the third phase), but the principles of this form of institutional ranking were established at the end of the 1600s and, in our understanding, consolidated the application in Portuguese America of structures of judicial ordering inspired by the metropole.

The third phase extends until the middle of the eighteenth century. More than half of the total number of ouvidorias, with a clear concentration in the 1720 s and 1730s (see Map 2), were created in this period. The context that justified this was the rush provoked by the exploration of mineral resources and the need for an administrative framework (especially judicial and fiscal) felt both by the Crown and by the locals. The historiography about Minas Gerais has taken into account the importance of this phenomenon in the political structure of the South-Central territory (Fonseca, 2010), as well as on the clear dislocation of the center of gravity of the state of Brazil to the south, with the growing polarization in Rio de Janeiro. The impacts of the intensification of the territorial occupation resulting from the discovery of mineral resources had an 
even broader spatial implication, with significant repercussions in the countryside in the north and northeast, as has been shown in various recent studies (Mello, 2012; Atallah, 2010; Sousa, 2012; Jesus, 2006).

\section{Map 2. Chronology of the creation of comarcas- 16th-18th centuries}

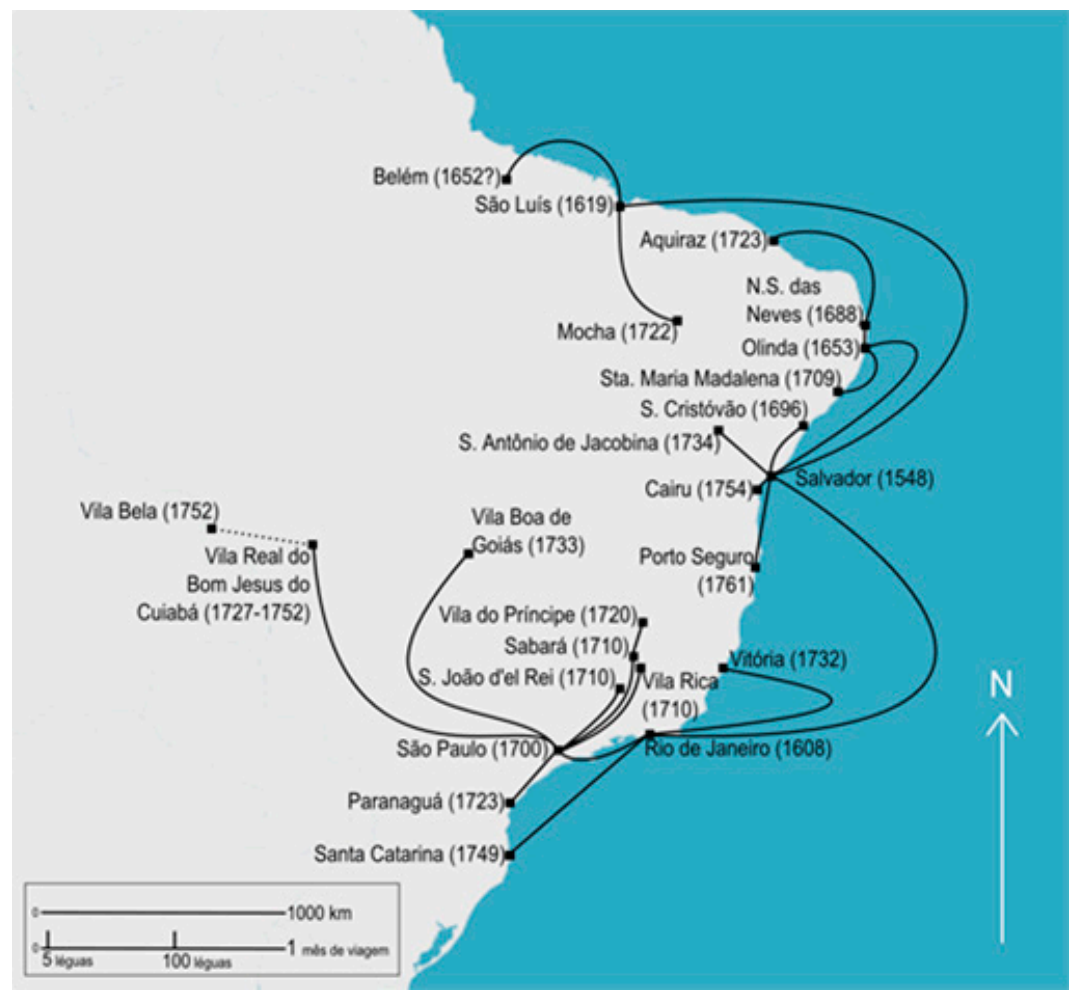

In this phase, regarding the judicial system, São Paulo stands out as a center of irradiation, possibly with a more relevant significance than Rio de Janeiro. Indeed, while the autonomization of the comarca in São Paulo (1700) - a result of the incorporation of the hereditary captaincy by the crown - occurred at the cost of the Southern ouvidoria-geral, headed by Rio de Janeiro. The expansive potential of São Paulo territory was already known by the elite from the previous hereditary captaincy of São Vicente, giving continuity to the ancestral dynamics of the penetration of the sertão from São Paulo (Vilardaga, 2010). It was for this reason that the royal captaincy of São Paulo, whose frontiers were open, was the one from which the other comarcas, and the new captaincies, were disaggregated. The dynamics of this process are varied and in some cases are rooted in Lisbon, while in others, and more frequently, in the crown's agents in the territory, mainly the governors and the ouvidores-gerais. This is how the rapid and precocious infrastructure of the territory of the new captaincy of Minas Gerais can be explained, since in a 10 year span it was divided into four comarcas: Ouro Preto, Rio das Velhas, Rio das Mortes (between 1711 and 1713) 
and Serro do Frio (1720), respectively based in the vilas (towns) of Vila Rica, Sabará, São João del-Rei and Vila do Príncipe (now Serro).

A similar phenomenon, although somewhat later, as it corresponds to the gradual advance of occupation to the interior resulting from the discovery of new veins of gold, can be observed in the creation of comarcas based in Vila Real do Bom Jesus de Cuiabá (1728, Mato Grosso) or in Vila Boa de Goiás (1733, ${ }^{12}$ Goiás) and Jacobina (1734, Bahia). The latter represents a new division of the large comarca of Bahia in a zone with uncertain borders with the mining comarcas. The new comarca based in Moche, currently Oeiras (1722, Piauí), disaggregated from the ouvidoria-geral of Maranhão, highlights the previously mentioned impact of the development of cattle raising to supply the new settlement centers.

With a dynamic of continuity with the two previous phases, as it originated coastally, the comarca headed by Aquiraz (1723, Ceará) resulted from the partition of the ouvidoria-geral of Paraíba, which thereby confirmed the transfer of the expansive dynamics previously witnessed in Pernambuco to this captaincy and comarca.

This acceleration, 'interiorization' and densification of the judicial system in Portuguese America constitutes the novelty in this third phase, which does not end with the creation of these 13 new ouvidorias. The royal judicial network also densified at its base through the spread of the juizados de fora, covering first the main cities (Rio de Janeiro and Recife) and, later, some vilas from mining zones in São Paulo and Minas Gerais (Camarinhas, 2010, p. 123).

Another new element in this period was the 'closing' of the borders of certain comarcas, which then came to have a much smaller and more delimited area, as happened with Rio de Janeiro following the emancipation of its neighboring territories to the north and south with the comarcas headed by Vitória (1732, Espírito Santo) and Santa Catarina, currently Florianópolis (1749). A similar process occurred in the south of Pernambuco, with the creation of the comarca of Alagoas, based in Santa Maria Madalena (1709). With the already mentioned exceptions of Paraíba and São Paulo, it seems that the general tendency up until the end of the period under analysis was the territorial stabilization of the comarcas created in these second and third phases, since, despite specific adjustments, they did not give rise to new divisions of the judicial system.

The fourth and final phase of this chronology covers the second half of the eighteenth century. Contrasting with the dynamism of the previous phase, only two new comarcas were created, both resulting from the dismemberment of the south of the comarca of Bahia and the Crown's incorporation of the hereditary captaincies of Ilhéus and Porto Seguro. These were: the ouvidorias of Cairu (1763, Ilhéus) and of Porto Seguro (1763). Also in this case, they were located on the coast, completing the emancipation of the judicial network, which was based on the division of the territory of donatary captaincies created two centuries before.

12 There are some doubts regarding this date. 
This deceleration in the construction of the network of ouvidorias deserves additional explanation, above all given the continued dynamic of colonization witnessed during this period. In our view, the explanatory hypothesis can enroot a new institutional experience which modified the administration model of justice set in the ouvidorias and appears to have been verified on three levels. First, with the creation of the High Court based in the most dynamic city in Portuguese America and which soon would become the capital of the state of Brazil: Rio de Janeiro (Wehling and Wehling, 2004). Second, a royal law of 1765, which proposed the creation of the Juntas de Justiça (Councils of Justice) in every part of Brazil where there was an ouvidor and which seems to have approximated the models of audiencias practiced in Spanish monarchy, including in their American domains. Although we do not know how it was applied, this law stipulated that the Juntas consist of the ouvidor, the 'president' and rapporteur of the body, and two assistants, lettered or with degrees (Cabral, 2013). It was a more collegiate model of decision-making, differing from the Spanish system due to the fact that there was no governor presiding over it, which in turn meant an express intention of separating government roles from the administration of justice. Finally, the third level was based on the continued creation of educated judicatures in a few of the urban nuclei (only four in the 1750s) and the outbreak, this time significant, of the creation of vilas. These last elements suggest a convergence of the Crown with the locals relative to the municipal model as a preferred form of political framing in the territory, regardless of the socially divergent dynamics which characterize so many of these processes.

\section{Analysis of the creation of comarcas}

Now we intend to analyze the processes of creation of new comarcas in Brazil, considering some elements in greater detail, such as the chronology of their creation, the entities that solicited them, the instances which intervened in the construction of the decision, as well as the list of arguments used in favor and against the establishment of the new ouvidorias. The importance of identifying the participants and the justifications presented in favor of the creation of the new districts is, above all, related to the need to comprehend who conceptualized the political organization of the territory and how it was done. The Crown? Administrative authorities? Local groups? Added to this is an interest in knowing if a determined judicial structure was repeatedly associated with a certain vision about the best manner of, through the division of territory, making the administration of justice more efficient. Recalling recent Brazilian historiographical debates - more specifically the criticism of the notion of an 'Ancient Colonial System' - , it is important to remember just how much these processes were influenced by various social agents. It can thus be questioned whether the political system, at least predominantly, had only been constructed from the top down, thereby revealing a harmony of interests between social 
groups which the defenders of this thesis often presented as being irreconcilable. In other words, and as we will see below, the role of the aforementioned agents in the territory puts into evidence the participation of the local elites in the creation of the comarcas, highlighting, this way, their capacity to promote and/or condition the configuration of the judicial network.

In relation to the actions of the Crown (more concretely the Conselho Ultramarino), it is important to perceive whether its role in this chapter was eminently reactive or if, to the contrary, the creation of new ouvidorias results from its initiatives, thereby entering the historiographical discussion about the construction of the state as predominantly driven by the political center or as a result of the participation of the local powers and the royal agents in the peripheries in the definition of the geopolitical organization of the territory, as well as the possible future components in the negotiation of these decisions.

Regarding royal agents in the territories, the focus will be placed on the action of the governors, viceroys and ouvidores. However, their participation should be situated in the ongoing debates regarding the motivations and interests of these officials. Since it is undeniable that they were not from the region to which they were appointed, this would give them, a priori, some distancing in terms of locally rooted clientele. However, one cannot ignore what Schwartz called the recurring 'Brazilianization' of these bureaucrats (Schwartz, 2011a, p. 254). This means that the participation of these individuals in the creation of new comarcas should be analyzed considering not only a search for improvement in the exercise of royal justice, but also the possibility of their position serving local, corporate, or even individual interests.

In relation to the intervention of local powers - especially the municipal councils - in the organization of the territory, the issues that are worth equating are significantly different. As well as the genuine interest in limiting recurring situations related to crime or defiance of authority, it should be taken into account that the creation of a comarca implied choosing a seat for it , a status often disputed by various vilas, since it gave them an undeniable supremacy over the others. Similarly, it is important to analyze in greater detail the discussions which the choice of location for the ouvidor generated, taking as a starting point the idea that a great availability of land in the Americas, in comparison with Portugal, allowed the application of some 'rationalization' criterion (Kantor, 2009, p. 234).

Nevertheless, it is worth remembering that at no time was there an attempt to generally reform the judicial network in Brazilian territory corresponding to a simultaneous reorganization in all of the ouvidorias. In this sense, the emergence of new districts of this type occurred in a more or less dispersed form throughout the seventeenth and eighteenth centuries. Plus, there were various 'advances and retreats' which often marked the position of the Crown in relation to a possible new comarca and the need to follow some of the requirements for a determined territory to be granted its own ouvidor. 
The time that passed between the request or the suggestion of the creation of a new ouvidoria and the approval of that request is another variable, which illustrates well the complexity of the entire system. While some comarcas such as Sergipe, ${ }^{13}$ Paranaguá, ${ }^{14}$ São Paulo, ${ }^{15}$ and Espírito Santo ${ }^{16}$ were authorized within a relatively short period of time - around two years - , in other cases, the decisions took much longer. Examples of comarcas whose cases took over a decade are Paraíba and Jacobina.

\section{At no time was there an attempt to generally reform the judicial network in Brazilian territory corresponding to a simultaneous reorganization in all of the ouvidorias}

Of the 23 comarcas analyzed here, it was possible to identify requests for the creation or dismemberment of 13 of them, though in some cases the establishment of the new ouvidoria was requested by more than one agent, which explains the fact that the number of suggestions are higher than the number of districts. ${ }^{17}$ Of this total, six came from ouvidores, four from governors of captaincies, five from municipal councils, and two from other spheres. Ouvidores, governors and municipalities therefore appear to be the main 'promoters' at the local level of the emergence of new judicial districts.

These numbers immediately raise an important question about the centers of local power and the 'intermediaries' in the definition of territorial organization, to an extent permitting the removal of the concept of the political-administrative division of space as a unilateral determination of the political center of the Portuguese Monarchy. The fact that it was found that over half of the comarcas arose out of requests from colonial spheres allows us to conclude that a large part of the Crown's activity in this area consisted of making assessments based on the information received, and not exactly acting at its own initiative. This does not, however, correspond to an absolute devaluation of its role. From the outset because it was the Overseas Council and, later, the Secretary

\footnotetext{
13 The request of the officials from the municipal council occurred in July 1694, and the first comarca was created in 1696: "Representação dos oficiais da câmara da capitania de Sergipe del Rey, ao rei [d. Pedro II], pedindo um ouvidor letrado para a capitania," AHU, Sergipe, box 1, doc. 62.

${ }^{14}$ The suggestion of the ouvidor of São Paulo is made in 1721, while the new ouvidoria was created in 1723 (Pegoraro, 2007, pp. 46-47).

15 In the case of São Paulo, the time was even shorter, with the request from the local municipal council being made in March 1698 and the creation occurring the following year (Pegoraro, 2007, p. 41). 16 This is certainly be one of the cases in which the decision was the extremely fast, since the suggestion of the ouvidor of Rio de Janeiro was made in April 1731, and the positive consultation of the Overseas Council dates from January of the following year: "Consulta do Conselho Ultramarino ao rei d. João V, sobre a carta do ex-ouvidor-geral do Rio de Janeiro, Manoel da Costa Mimoso [... e sobre uma carta do vice-rei do Estado do Brasil, conde de Sabugosa, [Vasco Fernandes César de Meneses], aludindo a necessidade de os moradores da vila de São Salvador dos Campos dos Goitacases terem um ouvidor-geral," AHU, São Paulo, box 23, doc. 2529

${ }^{17}$ Namely: Rio de Janeiro, Paraíba, Sergipe, São Paulo, Alagoas, Piauí, Paranaguá, Ceará, Cuiabá, Espírito Santo, Goiás, Jacobina, and Santa Catarina.
} 
of State for the Marine and Oversea which had decision making powers in this area. They could decide against the suggestions received and also, although the identification of such cases has shown to be more complex, elicit the reorganization they considered pertinent themselves. ${ }^{18}$ Consider as an example the cases of the various mining ouvidorias and those from Pernambuco. As some authors have emphasized, the organization of judicial space in Minas Gerais went through a relatively coordinated action whose origins were in the Crown, which, motivated by fiscal objectives, sought to endow this zone with tighter control mechanisms (Fonseca, 2011). Similarly, in the case of Pernambuco, the establishment of a royal ouvidoria in a hereditary captaincy would have aimed at greater limitation of the actions of the donatary (Adan, 2009, p. 47).

The arguments presented to the Conselho Ultramarino by the ouvidores, governors and municipalities are divided into two main types: those based on the excessive area of the districts which had existed until then, alleging the incapacity of the ouvidor to cross such great distances, and those which trace a generic context of the maladministration of justice. Although less recurrent, the population, economic activity and military administration also end up being elements taken into consideration in some cases.

As it is obvious, these are closely related arguments: the bad state of the justice was, in many cases, a result of the incapacity of a single official to cover such extensive territories. Nevertheless, a correlation between the justifications presented and certain judicial spheres is noticeable. Considering only the nine requests for comarcas made by ouvidores and governors (São Paulo, Alagoas, Piauí, Paranaguá, Ceará, Cuiabá, Espírito Santo, Goiás and Jacobina), it was found that seven alleged the unavailability of the former to carry out their roles in such a large area, with the magistrates emphasizing the enormous distances that separates the capitals of the districts from the farthest locations. The reasons presented by these two officials, however, are similar, which, in addition to finding their differences, highlights the harmony of some opinions among the agents supplied by the Crown.

In the concrete case of the ouvidores, the reason invoked is totally comprehensible, since the maladministration of justice in the area under their jurisdiction could be attributed to them. It also explains why they sought to present previous explanations for the bad performance of their roles. Still, this was not a consensual understanding among all the magistrates, or, better stated, some of these officials considered that other conditions existed to which priority should be given. These differences in understanding are the genesis of conflicts and discrepancies, such as the one which occurred following the creation of Paranaguá comarca. This comarca had resulted from the suggestion of the then ouvidor of São Paulo, Rafael Pardinho, in 1721. Following its creation, but before the arrival of the first magistrate to occupy a position there,

\footnotetext{
${ }^{18}$ An example of this situation was the refusal of the request made in 1791 by Brigadier Rafael Pinto Bandeira, commander of Rio Grande de São Pedro, for the creation of an ouvidoria in this captaincy: "Ofício do [comandante do Rio Grande de São Pedro], brigadeiro Rafael Pinto Bandeira, ao [secretário de estado da Marinha e Ultramar], Martinho de Melo e Castro..." AHU, Rio Grande do Sul, box 3, doc. 252.
} 
Pardinho's successor in the São Paulo comarca, Manuel de Melo Godinho Manso, had already informed the Conselho Ultramarino of his disapproval due to the significant loss of revenue which would result from this separation (Pegoraro, 2007, p. 47). This concrete case represents a situation in which two individuals who occupied the same role had two significantly opposing views regarding the same subject, with Godinho Manso clearly favoring his immediate personal interests.

It is thus evident that the decision of a determined ouvidor to suggest the dismemberment of his comarca was always the result of a ponderation of various factors. While it is true, that the smaller the size of a district, the greater the efficiency of its administrative justice, it cannot be ignored that the reduction of its earnings could alter the form in which these officials faced the division of 'their' comarcas. Nevertheless, it is impossible to ignore that, the ouvidores having previously alleged the difficulties created by the great distances they had to cross, had forearmed themselves against a negative result of the settlements they were subject to when they ended their functions, which, as is well known, could represent a hindrance to their progress in the cursus honorum of their magistracy in the Portuguese monarchy.

Focusing the analysis on the participation of the municipal councils in these processes, there are significant differences compared to the suggestions presented by ouvidores and governors. The number of cases is, from the beginning, lower, with only five requests to the Conselho Ultramarino by municipalities. In these cases, along with the councilors, the image of maladministration of justice and of all the adverse consequences which this situation generated in the administration of the day-to-day of the population was highlighted. Indirectly, this argument also represented a denunciation of how the ouvidores with jurisdiction over their territories fulfilled their roles.

The irregularities pointed out could be, as in the territories of Alagoas or Sergipe, the elevated number of criminals and the recurrence of "practices averse to the peace of the populations" (Prado, 1919, p. 94-95), but also complaints about the prepotency of magistrates, with the most paradigmatic case being Paraíba, in which the officials from the municipal council and residents of Nossa Senhora das Neves (currently João Pessoa) sought the provision of an ouvidor to limit the action and abuse of the provedor da fazenda (an official responsible for taxes and finances), who also held the position of provedor dos defuntos e ausentes (an official responsible for the administration of all questions related to the goods and will of the deceased), Salvador Dourado (Menezes, 2005, p. 90).

From this, it can be inferred that the interest of some municipal councils in appointing an ouvidor went beyond the need for speedier and more efficient justice. The existence of another sphere of power, especially if based in that vila, also represented a form of controlling other agents and providing a certain safeguard for the council about possible abuse from them. Pegoraro points out similar motivations for the request to create four comarcas in the region of 
the municipal council of São Paulo at the end of the seventeenth century. In his view, the municipality sought, through the provision of a new authority in the territory, to guarantee more stability in face of the disputes between heirs of the São Vicente captaincy (Pegoraro, 2007, p. 41).

The definition of the capital of the comarca was another significant argument, especially for the municipalities. Despite the natural interest that each municipal council had in its vila being chosen as the base for the ouvidoria, this question was of special interest if related to a more generic topic. While Hespanha and Cristina Nogueira da Silva have already emphasized the "political-administrative unavailability of space" (Hespanha, 2005, p. 94; Silva, 1998) as a preponderant factor in the impossibility of standards of rationality being followed in the organization of metropolitan territory under the Ancien Regime, the same logic could not be applied to Brazil, as can be observed in the choice of a base for the comarca. While, in some cases, the socioeconomic preponderance of certain vilas and cities, as well as their antiquity, such as São Paulo, Rio de Janeiro, São Luís and Bahia, made it difficult for other municipalities to aspire to this statute, other cases occurred where this did not happen. Examples of this are the comarcas from Alagoas and Ilhéus, both in the Northeast of Brazil, whose ouvidor settled in the villages of Santa Maria Madalena (currently Marechal Deodoro) and Cairu, respectively, although neither of these had the most economic relevance or the biggest populations. These choices would have been made due to the intention of having the ouvidorias in the most central region possible, which allowed the ouvidores to move through their jurisdiction homogenously (Caetano, 2009; Adan, 2009, p. 98). Other cases occurred, like Pernambuco and Mato Grosso, in which the capital of the comarca was changed many years after its creation. It remains clear, then, that contrary to what occurred in the metropolis, the definition of the capital of districts could result from criterion related to spatial rationality, although it should be emphasized that this was not always the case. ${ }^{19}$

Considering that a great part of the territories where new comarcas were created were in fact spaces of 'open frontiers,' in which the settling of population was practically limited to the small arraiais (camps) that gradually emerged (Russell-Wood, 2010, pp. 180-181), it is interesting to observe the sequence that the Portuguese Crown followed in the political framing of the populations (whether they were municipalities, ouvidorias, provedorias, or governments). In other words, attempting to perceive up to what point a logic existed (or not) which dictated, for example, that the institution of the comarca would have to be preceded by the existence of a municipality in its territory. It is therefore intended to clarify, for example, whether or not the establishment of a comarca took advantage of a pre-existing network of councilors in these regions or if, on the contrary, this would be the first structure of a judicial nature to be created.

${ }^{19}$ Cristina Nogueira da Silva discusses the application of different criteria to the attempt to reform metropolitan territory in 1790-1792 (Silva, 1998, p. 198-202). 
Indeed, individually analyzing each of the 23 comarcas that existed until the end of the eighteenth century, it can be observed that all of them had within their territories, when they were created, at least one vila. It should be emphasized, however, that in some cases, especially in the mining regions in the countryside of Brazil, such as Ouro Preto, Rio das Velhas, Rio das Mortes, Cuiabá and Goiás, the two spheres (municipal council and ouvidoria) were created practically simultaneously, although the establishment of the vila tends to come slightly before the provision of the first ouvidor.

The fact that the monarchy sought to ensure the chronological precedence of the municipality over the comarca is quite evident in the case of the ouvidoria in Piauí. The first request for the appointment of a magistrate occurred in 1712, when the ouvidor of Maranhão requested the provision of a juiz de fora for the territory. The request, however, was refused, while the ouvidor in question was told that he should first found a village and create its respective municipal council. ${ }^{20}$ In the same letter, the following was written: "once the vila in question has been established, let it be known so that the stated captaincy of Piauí can be provided with an ouvidor" (Costa, 1909, p. 75). The delay in the installation of the vila (which only occurred in 1717) slowed the process of creation of the ouvidoria, which was only decreed in 1722 following the information of the foundation of the vila. While the captaincy, despite being created in 1718, would only receive a governor in 1758 .

However, cases like this one in Piauí allow us to see that the creation of the vila sought, above all, to respond to the existing need of a municipality which assumed the statute of the 'capital' of a newly created comarca. As is noticeable in this case, notwithstanding the intention of the Crown to create an ouvidoria in the region, it was suspended until what could be considered as requirements for the creation of such a district were met, including the existence of a vila to serve as its base. In this sense, the fact that the monarchy opted for founding vilas before the provision of the first ouvidor should be seen more as a means of reaching the desired result, that is, the establishment of the comarca. There is no intention in undervaluing, among other things, the politics of the establishment of vilas, enhanced in various chronologies by the Crown, but merely noting the fact that, in some cases, especially in regions with 'open borders,' the urgency demonstrated in the creation of the municipality resulted from the attempt to achieve a wider objective. Furthermore, comparing the chronology of the creation of the comarcas with political periodization of the establishment of vilas proposed by Rhoden (1999), the similarities are quite evident. Thus, both the political-administrative reorganization of the Northeast at the end of the 1600s and the dismemberment of the new ouvidorias in the South-Central regions at the beginning of the eighteenth century tended to be accompanied by the appearance of villages and the consequent settling of population.

20 "Parecer do Conselho Ultramarino sobre a carta do ouvidor do Maranhão, [Eusébio Capelli], solicitando a criação do cargo de juiz de Fora, no Piau," AHU, Piauí, box 1, doc. 5. 
Something surprising seems to be the low impact that the population and the dynamic economy had in the arguments presented to the Conselho Ultramarino. The few allusions to these reasons - in which the comarcas from Jacobina and Pernambuco are exceptions - can be directly related to the fact that the distances, and consequently the 'spatial rationality standards,' are considered the preponderant factor in the decision-making process. Still, its importance should not be completely ignored, to the extent that the Conselho Ultramarino went as far as reconsidering the appointment of an ouvidor due to apparent tendencies of depopulation (Jesus, 2009) or the "poverty of the lands." 21

The safety of the borders, whether to the west (the region of Goiás and Cuiabá), or to the north (the state of Maranhão), also played a preponderant role in the decision for the creation of new ouvidorias in that zone. As Nauk Maria de Jesus points out for the case of Cuiabá, "according to the [Overseas] Council, the distance and the proximity with the Spanish demanded the appointment of an ouvidor by the metropolitan administration" (Jesus, 2009, p. 2). This position, not being interpreted as the acknowledgement of possible military competences from these magistrate, leaves it clear, however, that assuring the administration of the justice and the stability of these less populated regions was essential, considering that it would help to avoid possible territorial disputes with the Castilian Crown (Jesus, 2011).

The local powers and the royal agents (ouvidores and governors) in the territory, in many cases representing, as has been demonstrated, personal and corporate interests, had a central role in the various alterations which are found throughout these two centuries in the organization of the Brazilian territory, although the obligation for all proposals to pass through the careful eye of the central administration should be emphasized. Due to their knowledge of the territory, they were, theoretically, the most well positioned to suggest changes to the administrative network. However, as was opportunely pointed out, despite the progressive application of spatial rationality standards in these processes, it is not possible to ignore that many of the districts created, as well as their configuration, corresponded more to objectives of personal or institutional affirmation in a regional plan. These conclusions are encased in more interest if we consider the fact that, as Ernesto Schäfer pointed out long ago (2003, p. 79) and Burkholder and Chandler have confirmed (1977), a significant part of the audiencias created by the Castilian Crown in America originated from similar initiatives from the colonists. This data indicated, therefore, an elevated participation of the local spheres in the Ancien Regime Iberian monarchies.

It also seems evident that this long process of organizing the Brazilian territory is indissociable from the development of the urban network and that this fact helps to explain the densification of the creation of comarcas in the first half of the eighteenth century. The existence of more than a vila /town has been proved to be a determining factor in the participation of municipal councils in the creation of comarcas, since the dispute for the supremacy meant that they

${ }^{21} \mathrm{AHU}$, Alagoas, box 18, doc. 1792. 
sought to intervene in the process, trying to consolidate the status of head of the new ouvidoria. However, their participation, similarly to what occurred in the metropole (Silva, 1998, p. 166), reflected a central worry with the hierarchy of the territory deriving from the establishment of the new ouvidoria, and not exactly with the configuration of the new districts. Thus, the fact that the cases in which the participation of the councils is identified are, in their majority, located in the Northeast is justified. On the other hand, this was not a problem in the interior, where the creation of comarcas was accompanied by the establishment of a vila that was assumed to be the irradiating center of colonization.

\section{Conclusions}

As we have shown, the structure of the judicial network in Portuguese America cannot be detached from the dynamics of territorialization of the power that occurred in the governmental sphere. Thus, it seems evident that the late construction of the network of comarcas in Portuguese America and the configuration that it assumed were influenced by various factors, some of these endogenous to the judicial system as a whole, while others were clearly exogenous. In regard to the endogenous factors, it is important to emphasize the first condition associated with the initial form of royal donation of the hereditary captaincies, since it also implied the administration of justice. Indeed, the hereditary captaincies resisted the successive reorganization of their ownership for centuries, making evident the resilience of the jurisdictional political culture. Furthermore, it should be emphasized that the late implantation of the network of juizados de fora resulted from dynamics which did not always coincided with the dynamics of the Crown and the local elite class and of these two with the interests of the ouvidores. Indeed, this delay in the network of juizes de fora reveals a precedence and centrality to the ouvidores that their corresponding corregedores did not have in Portugal, since in Portuguese America for a century and a half the ouvidores were the only judicial agents for the Crown with a territorial base. Within this framework, both the option of inviting a juiz de fora to one of the cities of the comarca as well as the conflict with the recently arrived juízes de fora, or even the participation of the ouvidores in the delimitation of the new comarcas and their headquarters, can be interpreted as actions destined to the preservation of their jurisdictional competences. On the other hand, the delay in the structuring of the judicial system also highlights the role of the municipalities and the landed elites as central interlocutors of the monarchy in the construction of political space in Portuguese America.

But there were other constraints external to the judicial system. One of these is related to resilience, this time of the model of political division of space established in the captaincies. As one can observe, new comarcas tended to coincide with originating captaincies, unless when the new judicial districts corresponded to the interiorization of colonization or expansion toward the South. In this sense, with the exception of Minas Gerais, the coastal centers of 
irradiation of colonies persisted as the more dynamic throughout the two centuries, while the occupation of the sertão was quite late. And, furthermore, it is important to signal that the geography of new comarcas in the eighteenth century had an evident connection with the economic importance of settlement in the regions of Portuguese expansion.

Finally, it can be said that, if by comparison with Spanish America, the delay in the structuring of the judicial network in the states of Brazil and Maranhão can be explained through the delayed characteristic of Portuguese advancement over territory, the confrontation of both systems makes other differences apparent. From the beginning the greater inelasticity of the Spanish model in face of the flexible and unplanned nature of the system in Portuguese America, noting that the solutions found resulted both in the voluntarism of central powers and the initiatives of their own local authorities. In this sense, it should be highlighted that the construction of a royal political system (including the judicial system) had many protagonists and called upon the coexistence, even if fleeting, of social interests considered, by some authors, as contradictory or irreconcilable.

Mafalda Soares da Cunha is researcher at CIDEHUSInterdisciplinary Centre for History, Culture and Societies (UID/HIS/00057/2013); António Castro Nunes is researcher, and PhD Student of PIUDHist (Inter-University PhD Programme in History), CIDEHUS- Interdisciplinary Centre for History, Culture and Societies (UID/HIS/00057/2013). This article is part of the Portuguese-Brazilian project coordinated by Nuno G. Monteiro, "A comunicação política na Monarquia pluricontinental portuguesa (1580-1808): Reino, Atlântico e Brasil" (PTDC/HIS-HIS/098928/2008) and CIDEHUS program (UID/HIS/00057/2013 -POCI-01-0145-FEDER-007702). We would like to thank Ana Cristina Nogueira da Silva (FDUNL), Maria Fernanda Bicalho (UFF), Ronald Raminelli (UFF) and Nuno G. Monteiro (ICS-UL) for their careful comments. 


\section{Bibliographical references}

ADAN, Caio Figueiredo Fernandes. Colonial comarca dos Ilhéus: soberania e territorialidade na América Portuguesa (1763-1808). Tese (Mestrado em História), Universidade Federal da Bahia, Salvador, 2009.

ALDEN, Dauril. El Brasil colonial tardio, 1750-1808. In: BETHELL, Leslie (Ed.). Historia de America Latina. América Latina Colonial: Economía. Barcelona: Editorial Crítica, 2000 [1984]. v. 3, p. 306-358.

ASSIS, Virgínia Almoedo de. Palavra de rei: autonomia e subordinação da capitania hereditária de Pernambuco. Tese (Doutorado em História), Universidade de Federal Pernambuco, Recife, 2001.

ATALLAH, Cláudia. Da justiça em nome d'el Rey: ouvidores e inconfidência na capitania de Minas Gerais (Sabará, 1720-1777). Tese (Doutorado em História Social), Universidade Federal Fluminense, Niterói, 2010.

AZEVEDO, Paulo Ormindo de. Porto Seguro. Enquadramento Histórico e Urbanismo. Património de Influência Portuguesa. Available at: <http://www.hpip.org/Default/ $\mathrm{pt} /$ Conteudos/Navegacao/NavegacaoGeograficaToponimica/Localidade?a=69>.

Accessed on: 16 Sept. 2015.

BURKHOLDER, Mark A.; CHANDLER, D. S. From impotence to authority: the Spanish Crown and the American audiencias, 1687-1808. Columbia/London: University of Missouri Press, 1977.

CABRAL, Dilma. Juntas de Justiça. 2013. Avilable at: <http://linux.an.gov.br/ mapa/?p=4213>. Accessed on: 3 Sept. 2015.

CAETANO, António Pereira. "Por ser público, notório e ouvir dizer...": queixas e súplicas de uma conquista colonial contra seu ouvidor (Vila de Penedo, 1722). Revista Espaço \& Tempo, n. 2-3, p. 18-40, 2009. Available at: <http://ufal-geac.com.br/wp-content/ uploads/Microsoft-Word-Revista-Espa\%C3\%A7o-Tempo-Por-Ser-P\%C3\%BAblicoNot\%C3\%B3rio-e-Ouvir-Dizer.pdf>. Access on: 14 Jan. 2014.

CAMARINHAS, Nuno. Juízes e administração da justiça no Antigo Regime: Portugal e o império colonial, séculos XVII e XVIII. Lisboa: Fundação Calouste Gulbenkian/ Fundação para a Ciência e a Tecnologia, 2010.

CARRARA, Ângelo Alves. A população do Brasil, 1570-1700: uma revisão historiográfica. Revista Tempo, v. 20, p. 1-21, 2014.

COSENTINO, Francisco. Governadores gerais do Estado do Brasil (séculos XVI - XVII): ofício, regimento, governação e trajetórias. São Paulo: Annablume/Fapemig, 2009.

COSTA, Francisco Pereira da. Chronologia historica do Estado do Piauhy. Rio de Janeiro: Artenova, 1909.

EIRAS ROEL, Antonio. Prólogo. In: FERNANDEZ VEGA, Laura. La real audiencia de Galicia organo de gobierno en el Antiguo Regimen (1480-1808). La Coruña: Diputación Provincial, 1982. t. I, p. 15-49.

ELLIOTT, J. H. Empires of the Atlantic world: Britain and Spain in America, 1492-1830. New Haven/Londres: Yale University Press, 2007.

FONSECA, Cláudia Damasceno. Arraiais e Vilas del Rei: espaço e poder nas Minas setecentistas. Belo Horizonte: UFMG, 2011.

FURTADO, Júnia Ferreira. Homens de negócio: a interiorização da metrópole e do comércio nas minas setecentistas. São Paulo: Hucitec, 1999.

Introdução. In: COUTO, José Vieira. Memória sobre a capitania das Minas

Gerais: seu território, clima e produções metálicas. Belo Horizonte: Fundação João Pinheiro, 1994 [1799].

GOMES, José Eudes. As milícias d'el rey: tropas militares e poderes no Ceará setecentista. Rio de Janeiro: FGV, 2010.

GÓMEZ GONZÁLEZ, Inés. La justicia, el gobierno y sus hacedores: la Real Chancillería de Granada en el Antiguo Régimen. Granada: Comares, 2003.

HESPANHA, António Manuel. A constituição do Império Português, revisão de alguns enviesamentos correntes. In: BICALHO, Maria Fernanda B. et al. (Org.). Antigo Regime nos trópicos: a dinâmica imperial portuguesa (séculos XVI-XVIII). Rio de Janeiro: Civilização Brasileira, 2001. p. 163-188. 
. As vésperas do Leviathan. Instituições e poder político: Portugal (século XVII). Coimbra: Almedina, 1994.

. História de Portugal moderno, político e institucional. Lisboa: Universidade

Aberta, 2005.

JESUS, Nauk Maria de. A administração da justiça: ouvidores e regentes na fronteira oeste da América portuguesa. In: GUEDES, Roberto (Org.). Dinâmica imperial no Antigo Regime português: escravidão, governos, fronteiras, poderes, legados. Rio de Janeiro: Maud, 2011. p. 173-197.

. Na trama dos conflitos: a administração na fronteira oeste da América Portuguesa (1719-1778). Tese (Doutorado em História), Universidade Federal Fluminense, Niterói, 2006.

. Regência, regentes e ouvidores: a Câmara Municipal de Vila Real do Senhor Bom Jesus do Cuiabá (primeira metade do século XVIII). In: XXV SIMPÓSIO NACIONAL DE HISTÓRIA - HISTÓRIA E ÉTICA. Anais... Fortaleza: Anpuh, 2009.

JUCÁ NETO, Clovis Ramiro. Os primórdios da organização do espaço territorial e da vila cearense: algumas notas. In: MUSEU PAULISTA: HISTÓRIA E CULTURA MATERIAL. Anais..., v. 20, n. 1, jan./jun. 2012.

KANTOR, Íris. Soberania e territorialidade colonial: Academia Real de História Portuguesa e a América Portuguesa (1720). In: DORÉ, Andréa; SANTOS, Antonio Cesar de Almeida (Org.). Temas setecentistas: governos e populações no Império Português. Curitiba: UFPR-SCHLA/Fundação Araucária, 2009. p. 233-239.

LIMA JUNIOR, Francisco Antônio Carvalho de . Limites entre Sergipe e Bahia (estudo histórico). Revista Trimestral do IHGS, n. 3, p. 9-49, 1914.

LIVI BACCI, Massimo. 500 anos de demografia brasileira: uma resenha. Revista Brasileira de Estudos de População, v. 19, n. 1, p. 141-159, jan./jun. 2002.

LUCENA, Manuel. Atlas histórico de Latinoamérica: desde la prehistoria hasta el siglo XXI. Madri: Síntesis, 2005.

MARCÍLIO, Maria Luisa. La población del Brasil colonial. In: BETHELL, Leslie (Ed.). Historia de America Latina. América Latina Colonial: población, sociedad y cultura. Barcelona: Crítica, 2000 [1984]. v. 4, p. 39-60.

MARQUES, Guida. De um governo ultramarino: a institucionalização da América Portuguesa no tempo da União das Coroas (1580-1640). In: CARDIM, Pedro; COSTA, Leonor Freire; CUNHA, Mafalda Soares da (Org.). Portugal na Monarquia hispânica: dinâmicas de integração e conflito. Lisboa: CHAM-UNL/UAç/Cidehus-UÉ/GHESUTL, 2013. p. 231-252.

. Entre deux empires: le Maranhão dans l'Union Ibérique (1614-1641). Nuevo Mundo Mundos Nuevos [on-line], Débats, 23 mar. 2010. Available at: <http://nuevomundo.revues.org/59333>. Accessed on: 3 Sept. 2015.

MELLO, Isabele de Matos Pereira de. Magistrados a serviço do rei: a administração da justiça e os ouvidores-gerais na comarca do Rio de Janeiro (1710-1790). Tese (Doutorado em História), Universidade Federal Fluminense, Niterói, 2012.

MENDONÇA, Marcos Carneiro de. Raizes da formação administrativa do Brasil. Rio de Janeiro: IHGB/Conselho Federal de Cultura, 1972. t. II.

MENEZES, Mozart Vergettide. Colonialismo em ação: fiscalismo, economia e sociedade na capitania da Paraíba (1647-1755). Tese (Doutorado em História), Universidade de São Paulo, São Paulo, 2005.

MONTEIRO, Nuno G. O central, o local e o inexistente regional. In: OLIVEIRA, César de (Org.). História dos municípios e do poder local em Portugal dos finais da Idade Média à União Europeia. Lisboa: Círculo de Leitores, 1996. p. 79-119.

MORAES, Antônio Carlos Robert. Bases da formação territorial do Brasil: o território colonial brasileiro no "longo" século XVI. São Paulo: Hucitec, 2000.

PEGORARO, Jonas Wilson. Ouvidores régios e centralização político-administrativa na América portuguesa: a comarca de Paranaguá (1723-1812). Dissertação (Mestrado em História), Universidade Federal do Paraná, Curitiba, 2007.

PRADO, Ivo do. A capitania de Sergipe e suas ouvidorias: memória sobre questões de limites (Congresso de Belo Horizonte). Rio de Janeiro: Papelaria Brazil, 1919 [reimpr. de 2011]. 
REIS FILHO, Nestor Goulart. Evolução urbana do Brasil: 1500-1720. São Paulo: Pioneira, 1968. v. 1.

RHODEN, Luiz Fernando. Urbanismo no Rio Grande do Sul: origens e evolução. Porto Alegre: EDIPUCRS, 1999.

RUBIM, Braz da Costa. Memórias históricas e documentadas da província do Espírito Santo. Rio de Janeiro: Typographia de D. Luiz dos Santos, 1861.

RUSSELL-WOOD, A. J. Padrões de colonização no Império Português. In: BETHENCOURT, Francisco; CURTO, Diogo Ramada (Org.). A expansão marítima portuguesa, 1400-1800. Lisboa: Edições 70, 2010. p. 171-206.

SALDANHÁ, António Vasconcelos de. As capitanias do Brasil: antecedentes, desenvolvimento e extinção de um fenómeno atlântico. Lisboa: CNCDP, 2000.

SALGADO, Graça (Org.). Fiscais e meirinhos: a administração no Brasil colonial. Rio de Janeiro: Nova Fronteira, 1985.

SCHWARTZ, Stuart B. Burocracia e sociedade no Brasil colonial: o Tribunal Superior da Bahia e seus desembargadores, 1609-1751.2. ed. São Paulo: Companhia das Letras, 2011a [ed. original de 1973 e primeira tradução portuguesa de 1979].

. The historiography of early modern Brazil. In MOYA, José C. (Org.). The Oxford handbook of Latin American History. Nova York: Oxford University Press, 2011b. p. 98-131. SILVA, Ana Cristina Nogueira da. O modelo espacial do Estado moderno: reorganização territorial em Portugal nos finais do Antigo Regime. Lisboa: Estampa, 1998.

. Comarca. In: SERRÃO, José Vicente; MOTTA, Márcia; MIRANDA, Susana Münch (Org.). e-Dicionário da terra e do território no Império Português. 2014. Available at: <http://edittip.net/category/comarca/>. Accessed on: 28 Aug. 2015.

SILVA, Augusto da. A ilha de Santa Catarina e sua terra firme: estudo sobre o governo de uma "capitania" subalterna (1738-1807). Tese (Doutorado em História), Universidade de São Paulo, São Paulo, 2007.

SILVA, Evandro Bezerra da. Mandos e desmandos: os ouvidores da capitania de Pernambuco no reinado de d. João V (1709-1750). Dissertação (Mestrado em História), Universidade Federal de Pernambuco, Recife, 2010.

SILVA, Maria Beatriz Nizza da. Administração judiciária. In: SILVA, M. B. N. (Org.). Dicionário da história da colonização portuguesa no Brasil. Lisboa: Verbo, 1994. p. 24-25. SOUSA, Maria Eliza Campos. Ouvidores de comarcas na capitania de Minas Gerais no século XVIII (1711-1808): origens sociais, remuneração de serviços, trajetórias e mobilidade social pelo "caminho das letras". Tese (Doutorado em História), Universidade Federal de Minas Gerais, Belo Horizonte, 2012.

SUBTIL, José. O desembargo do Paço: 1750-1833. Lisboa: UAL, 1996.

VILARDAGA, José Carlos. São Paulo na órbita do império dos Felipes: conexões castelhanas de uma vila da América Portuguesa durante a União Ibérica (1580-1640). Tese (Doutorado em História Social), Universidade de São Paulo, São Paulo, 2010.

WEHLING, Arno; WEHLING, Maria José. Direito e justiça no Brasil colonial: o Tribunal da Relação do Rio de Janeiro (1751-1808). Rio de Janeiro: Renovar, 2004. 